AMERICAN PEDIATRICS 



\title{
AMERICAN PEDIATRICS
}

\author{
The Social Dynamics of \\ Professionalism, 1880-1980
}

SYDNEY A. HALPERN

University of California Press

BERKELEY LOS ANGELES LONDON 
University of California Press

Berkeley and Los Angeles, California

University of California Press, Ltd.

London, England

Copyright 1988 by The Regents of the University of California

Library of Congress Cataloging-in-Publication Data

Halpern, Sydney A. (Sydney Ann)

American pediatrics.

Bibliography: p.

Includes index.

1. Pediatrics-United States-History

I. Title. [DNLM: 1. Pediatrics-history-

United States. 2. Professional Practice-history-

United States. WS 11 AA1 H12a]

$\mathrm{RJ}_{42 .} \mathrm{U}_{5} \mathrm{H}_{3} 6 \quad 1988 \quad 3^{62 . I^{\prime} 9892^{\prime}{ }^{\prime} 00973 \quad 87-30222}$

ISBN 0-520-05195-5 (alk. paper)

Printed in the United States of America

$\begin{array}{lllllllll}1 & 2 & 3 & 4 & 5 & 6 & 7 & 8 & 9\end{array}$ 
To the memory of my father Jules Halpern, physicist 
